\title{
Determination Cost of Sales and Utilization of Internet Media for SMEs Marketing in Kelanggaran Unyur
}

\author{
Khoirul Aswar and Ermawati
}

\begin{abstract}
The development of several food preparations in Kelanggaran Village, Unyur Serang, Banten, are craftsmen who diversify their processed products of various sizes, shapes, and types. The increase in the amount of production produced by craftsmen often neglects to be unable to determine the expected profit target related to material spending, production processes to marketing, so that prices are formed only based on estimates. In addition, this service aims to provide understanding to the craftsmen of special food processing. It is hoped that after this service, they can determine the cost of goods sold themselves and be able to market these special processed foods through the internet for their business. The implementation method in the program uses the participatory follow-up assessment method for IbM partners. This method is carried out because of the need for a partner situation analysis stage in the form of a field visit to the partners. To solve the solution to the problems faced by food processing craftsmen as partners, it is carried out in the form of a series of activities. Based on the results of direct observations, discussions and direct questions and answers during the activity, namely increased knowledge and understanding of determining the cost of goods sold and the use of internet media in the micro food / souvenir business typical of Serang City, this can be seen from the results of observations, discussions and questions and answers. during the training process.
\end{abstract}

Index Terms - SMEs, Cost of goods sold, Micro enterprises, Internet media, Community service.

\section{INTRODUCTION}

The rapid trade in Serang has resulted in more advanced economic growth, this can be seen in the Rau wholesale market, the old market and the royal area. One of the typical food processing industries in the village of Kelanggaran Unyur, Serang City, such as glutinous rice opak, rengginang, gipang, melinjo chips, and fish meatball crackers are still developing and have been able to survive quite well until now [1]. This can be seen by the increasing number of craftsmen who process specialties in the area. This typical food processed for current conditions has the potential to develop better and bigger, this is because it is increasingly recognized by people in the city of Serang and outside the city of Serang.

However, even though small businesses have extraordinary fighting power, to survive and develop, other supports are needed to increase their competitiveness and growth power. With the existence of the SMEs sector, unemployment due to the labor force that is not absorbed in the world of work is reduced. The MSME sector has also proven to be a strong economic pillar [5].

The development of typical food processing in the village of Kelanggaran Unyur, Serang City, the craftsmen diversified

Published on September 16, 2020.

Khoirul Aswar, Universitas Pembangunan Nasional Veteran Jakarta, Indonesia.

(e-mail: aswar_law@yahoo.com) into various sizes, types and shapes. However, the greater the amount of production produced by the craftsmen resulted in not recording financial problems from the process of purchasing raw materials to marketing, so that the craftsmen only used perceptions or estimates to determine the price. But in fact, the food processing craftsmen have not been able to report the cost of goods sold. Financial reports are the main means used by companies to communicate financial information to outside parties. The financial report is the history of the company as measured in units of money [4].

Based on the discussion with the village food processing craftsmen, the village food violations faced by the city of Serang are still unable to make a basic price report so this activity aims to provide training in making basic prices for the craftsmen and has not been managed professionally so that the development of this business is static and only sufficient for family meal. According to the Banten province's Office of Cooperatives and SMEs, the weakness of SMEs in Banten is that the problem of recording and financial reporting is very important for production and trade business activities. Financial recording is basically an accounting activity to provide accountability for trading activities carried out [6]. This accountability is very important in order to develop the business that has been and will be done and to find out the turnover obtained. In fact, most of Serang City's food preparations have not kept financial records properly. To overcome this problem, it is necessary to provide guidance and assistance regarding the recording of the cost of goods sold for craftsmen of typical food processing in the village of Kelanggaran Unyur, Banten.

Besides that, the craftsmen face the problem of the narrow marketing reach and the low ability of the craftsmen to use the internet as a marketing tool. This is said to be the network effect, meaning that product sales are not only related to quality alone but also to the extent of the network associated with the product [3]. This condition results in the need for network development, one of which is through the internet. The lack of knowledge and skills of special food processing craftsmen in utilizing internet media in increasing sales of the products produced is not optimal. Therefore, it is necessary to carry out training activities for craftsmen of typical food processing in the village of Kelanggaran Unyur, Banten city related to the use of internet media to increase marketing reach.

Furthermore, the craftsmen have so far only fulfilled the needs of the local area of the city of Serang, but the craftsmen wish to increase sales results by using more marketing by using online marketing and making a better display of the

Ermawati, Universitas Pembangunan Nasional Veteran Jakarta, Indonesia. (e-mail: gema_upn@yahoo.com). 
typical food processed in the village of Kelanggaran. The obstacles faced by these special food processing craftsmen are that the packaging used is still very simple and the packaging is still plain or there is no label. The product being marketed is relatively unattractive, so the sale is cheaper. Meanwhile, the product label is in great demand by consumers and will be an influence in itself thereby increasing production sales. The food processing is very limited and the craftsmen usually market this processed food directly to consumers and market traders who are in the village of Kelanggaran Unyur, Banten.

To attract interest from consumers, this food processing craftsman is redesigning the packaging to make it more attractive so that it can increase the selling power of the food processed. In this regard, the craftsmen need to understand and understand how to market this food process through online media. Because online media has become a necessity for urban communities and the craftsmen have not utilized the media optimally to get a better turnover. This technology can be used as a medium for marketing this food processor. In this internet media, food processing craftsmen can display the production process to marketing. So that it can increase the amount of production and absorb more labor which in turn can also increase the income of the people in the area.

\section{IMPLEMENTATION METHOD}

The activity begins with conducting a situation analysis through field visits, holding group discussion forums with food processing craftsmen to formulate the most appropriate alternative solutions and then planning activities to be implemented such as preparation of solutions \& preparation of training schedules, implementation of training, guidance, mentoring, and monitoring and evaluation.

The first stage of community service activities in the village of Kelanggaran Unyur is the preparation stage. The preparation stage includes training materials, training venues, training participants for 24 special food processing craftsmen. In addition, the preparation of facilitators and instructors consisting of two lecturers and two students, determining the timing of the training and preparing the facilities and infrastructure.

The second stage after preparation is the implementation stage. Community service activities are carried out in the form of training. The training is carried out in two stages. First, during two meetings in the form of providing material on the cost of sales and internet media. The second stage is in the form of practice, namely the practice of recording the cost of goods sold and the internet as a means of marketing typical processed food products. In this second stage the training participants are made into four (4) groups with each group consisting of six (6) people to practice the material that has been presented. The second stage will be held in two meetings.

The next stage is the Evaluation stage. At this stage, it is carried out by: a) assessing the ability of the training participants to make the cost of production and internet media as a means of marketing their products, b) assessing the level of activity of the training participants. c) assess the attendance level of participants during the activity.

\section{RESUlTS AND DISCUSSION}

At this stage it is the implementation of the solution by the IbM team to the food / souvenir micro business group typical of the city of Serang. The implementation of the activity began with the results of the situation analysis and the partner's solution plan, a meeting was held with the women of the food / souvenir micro business group typical of the city of Serang on February 20, 2020 at 07.00 in Kelanggaran Village, Unyur Serang, Banten. The meeting was attended by 15 group women. food / souvenir micro business typical of the city of Serang. The results of the discussion meeting were agreed between partners and the IbM team. The next stage, namely this community service activity attended by 15 participants of the micro food / souvenir business typical of the city of Serang which was held on July 19, 2020. This activity was positively welcomed by the villagers of Kelanggaran Unyur in the form of a Forum Discussion Group (FGD) between the community service team and partner group. Based on the results of direct observations, discussions and direct questions and answers during community service activities gave results, namely increased knowledge and understanding of determining the cost of goods sold and the use of internet media in a typical food / souvenir business in Serang City, this can be seen from the results of observations, discussion and question and answer during the training process.

Figures 1, 2 and 3 show the housewives of the Serang city specialty food processed group in carrying out the training activities that were followed. In this community service activity the provision of material was carried out by the community service implementation team consisting of lecturers and students as a technical assistance team for the implementation of the Community Service.

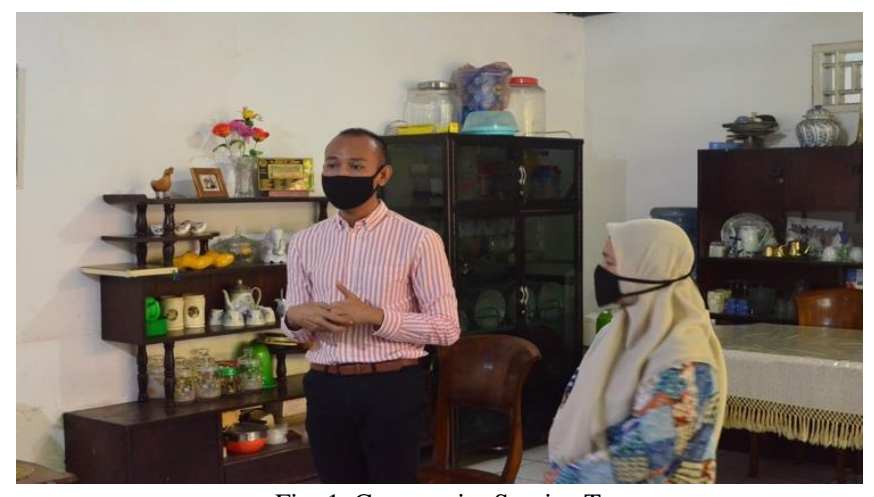

Fig. 1. Community Service Team.

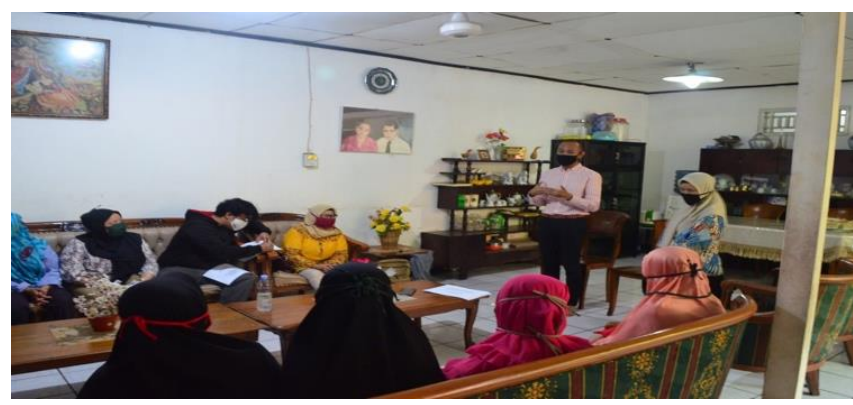

Fig. 2. Delivery of Material by Community Service Team - Training on Determining HPP and Utilizing Internet Media. 


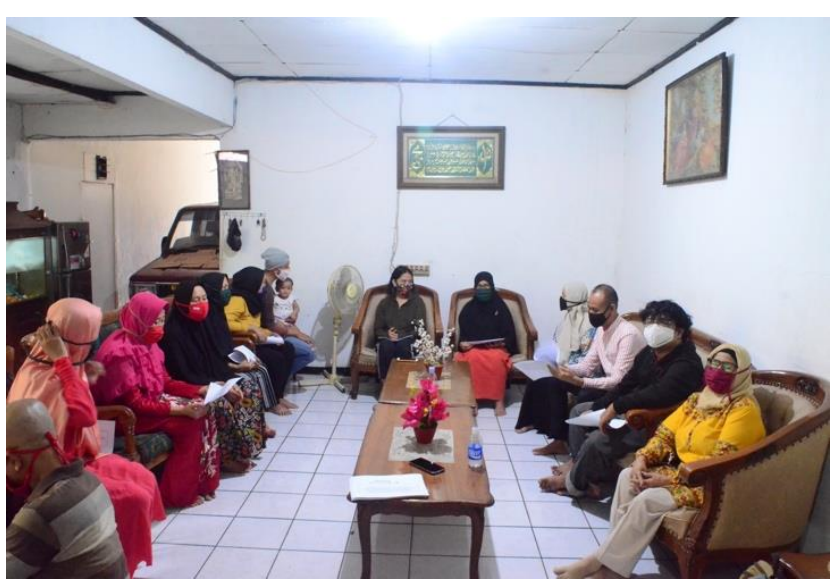

Fig. 3. Training Discussion on Determination of cost of sales and Utilization of Internet Media.

The problem of recording and determining the cost of goods sold for most of the food / souvenir micro business groups typical of the city of Serang is still not well organized. Financial recording is basically an accounting activity to provide accountability for trade and production activities carried out [6]. This accountability is very important in the context of efforts to develop the business that has been and will be carried out and to find out the turnover obtained. To achieve this goal, the community service team conducted training on recording cost of goods sold in increasing sales turnover using the internet media.

The training activity begins by introducing various kinds of production costs, cost classification, and production cost reports. Then done by practicing questions related to determining the cost of goods sold. This training received a positive response from the training participants and was enthusiastic about this micro business training. The obstacle faced by micro businesses is the difficulty in analyzing the transactions that occur so that recording experiences problems. Furthermore, after being explained again, they are able to record and determine the cost of goods sold for their business.

\section{CONCLUSION AND RECOMMENDATIONS}

The micro-food / souvenir business typical of the city of Serang, which is located in the village of Kelanggaran, Unyur Serang, Banten, is a hereditary business that has been carried out. This business is a home industry as a source of livelihood for local residents. Efforts that are made really need guidance, guidance that is carried out does not have to be provided by the Government Service. The role of universities can also help improve the skills of the craftsmen. Capacity building can be done by providing training such as training in compiling cost of goods sold and using internet media. This training is considered important in the hope that the craftsmen can improve the determination of the cost of goods sold so that the craftsmen's standard of living will be better.

Suggestions for improving the skills of a typical food / souvenir business in the city of Serang should not only focus on cost of goods sold training, marketing using social media such as Instragram, WhatsApp, Facebook, Wordpress also needs improvement.

\section{REFERENCES}

[1] Aswar, K., and Ermawati. E. (2019). Peningkatan keterampilan penyusunan laporan keuangan bagi kelompok usaha mikro makanan khas kota daerah kota Serang. Sabdamas, 96-100.

[2] Boyd, D.M. Ellison, and Nicole B., (2007) Social Network Sites: Definition, History, and Scholarship. Journal of Computer Mediated Communica-tion: Vol 13 No 1.

[3] Gretz, R. T., \& Basuroy, S. (2013). Why Quality May Not Always Win : The Impact of Product Generation Life Cycles on Quality and Network Effects in High-tech Markets. Journal of Retailing. 89(3), 281300 .

[4] Kieso and Weygandt. (2005). Akuntansi Intermediate. Edisi Ketujuh Jilid Satu. Jakarta: Bina Rupa Aksara.

[5] Lantu, D.C., Triady. M.S., Utami, A.F., dan Ghazali, A. (2016). Pengembangan Model Peningkatan Daya Saing UMKM di Indonesia: Validasi Kuantitatif Model. Jurnal Manajemen Teknologi. 15 (1). $77-$ 93.

[6] Standar Akuntansi Keuangan- Entitas Tanpa Akuntanbilitas Publik. Mei 2009. Ikatan Akuntan Indonesia. 